Małgorzata Pietrasiak

(Uniwersytet Łódzki)

\title{
Nowe kierunki współpracy politycznej państw ASEAN wobec współczesnych wyzwań
}

\section{Podstawy instytucjonalne współpracy politycznej ASEAN}

Stowarzyszenie Narodów Azji Południowo-Wschodniej (Association of South-East Asian Nations - ASEAN) powstało w sierpniu 1967 r. Jego członkami-założycielami były: Indonezja, Malezja, Filipiny, Singapur i Tajlandia. Celem podstawowym, jaki stawiała sobie wówczas ta organizacja regionalna, stało się współdziałanie państw członkowskich, umożliwiające przyspieszenie wzrostu gospodarczego, rozwoju społecznego, kulturowego w przyjaznym i pokojowym otoczeniu międzynarodowym. Obok problemów natury gospodarczej państwa te jednoczył jeszcze problem wojny indochińskiej, wynikająca z niej destabilizacja i stałe zagrożenie dla regionu oraz obawa przed wzrostem wpływów partii komunistycznych. Okres powołania do życia Stowarzyszenia łączył się z zapoczątkowaniem procesów normalizacyjnych i zbliżeniem stanowisk członków-założycieli w kwestii sojuszu ze Stanami Zjdnoczonymi. Tak więc po upadku lewicowych rządów w Indonezji w roku 1965 i dojściu do władzy proamerykańskiego generała Suharto, w kolejnym roku nawiązano stosunki dyplomatyczne z Malezją, kończąc konflikt z tym państwem, który trwał od 1964 r. W tym samym czasie z Federacji Malajsko-Singapurskiej wystapił Singapur, tworząc niezależne państwo. Tajlandia $\mathrm{z}$ początkiem lat sześćdziesiątych stała się, podobnie jak wcześniej Filipiny, jednym $\mathrm{z}$ najważniejszych sojuszników Ameryki w regionie. Na konferencji założycielskiej w Bangkoku postanowiono, że podstawową formą konsultacji i współpracy będą coroczne spotkania ministrów spraw zagranicznych (AMM).

W pierwszym okresie istnienia, głównie za sprawą niesprzyjającej sytuacji międzynarodowej, ale również z powodu nierozwiązanych konfliktów w regionie, nie udało się Stowarzyszeniu rozwinąc efektywnych form współpracy. Organizowane konferencje i spotkania były jedynie okazją do wzajemnego poznawania się, przekonywania partnerów o woli współpracy i szczerości intencji. Dopiero w roku 1971 udało się członkom ASEAN uzgodnić i podpisać Deklarację malezyjską o utworzeniu strefy pokoju, wolności i neutralności w regionie Azji Południowo-Wschodniej (Declaration on the Zone of Peace, 
Freedom and Neutrality - ZOPFAN). W Deklaracji potwierdzona została fundamentalna zasada, na której opiera się współpraca państw członkowskich: niemieszanie się $\mathrm{w}$ wewnętrzne sprawy drugiego państwa oraz poszanowanie wolności, niepodległości i integralności terytorialnej ${ }^{1}$. Deklaracja ZOPFAN wyrażała brak zgody państw ASEAN na mieszanie się w sprawy regionu wielkich mocarstw: Chin, Japonii, ZSRR, Stanów Zjednoczonych i przejęcie odpowiedzialności za bezpieczeństwo przez członków ASEAN. Nie została wówczas poparta przez Wietnam, będący ważnym uczestnikiem stosunków międzynarodowych w regionie, który krytykował nieszczerość podjętych zobowiązań i w pierwszej kolejności postulował zlikwidowanie amerykańskich baz wojskowych. Strategia wietnamska zakładała, że stosunki w regionie winny się opierać na „wzajemnym szacunku, niezależności, suwerenności, jedności terytorialnej, nieagresji, niemieszaniu się w wewnętrzne sprawy, równoprawności i pokojowym współistnieniu"”2.

Po zakończeniu okresu zimnowojennego reaktywowano i ulepszono ideę ZOPFAN. Na 26. Konferencji ministerialnej (AMM) w Singapurze w 1993 r. strony zdecydowały się rozwinąc kontakty dwu- i wielostronne, aby wzmocnić tendencje pokojowego rozwoju, stabilizacji itd., także przy wykorzystaniu mechanizmów w ramach Układu o przyjaźni i współpracy (Treaty of Amity and Cooperation - TAC). Strategia związana z ZOPFAN jest elastyczna i bierze pod uwagę różnorodność uwarunkowań zewnętrznych: ideologicznych, politycznych, społecznych, kulturowych, naukowych, technologicznych i sojuszów obronnych.

W lutym 1976 r. przyjęto drugi z podstawowych, wyznaczających kierunki współpracy politycznej i bezpieczeństwa dokumentów - Układ o przyjaźni i współpracy w Azji Południowo-Wschodniej, który określał zasady współpracy:

- wzajemne poszanowanie niepodległości, suwerenności, równości, terytorialnej integralności, tożsamości narodowej członków;

- prawo każdego państwa do kształtowania swojej egzystencji niezależnie od nacisków zewnętrznych;

- niemieszanie się w wewnętrzne sprawy drugiego państwa;

- rozwiązywanie sporów metodami pokojowymi;

- zakaz groźby użycia siły;

- efektywną współpracę między państwami członkowskimi³.

15 grudnia 1987 r. 6 członków ASEAN: Brunei, Indonezja, Malezja, Filipiny, Singapur i Tajlandia podpisało dodatkowy protokół TAC, w którym zmieniono brzmienie artykułów: 14 i 18, w ten sposób otwierając drogę przystapienia

${ }^{1}$ Zone of Peace, Freedom and Neutrality Declaration, Malaysia, 27 November 1971, www.aseansec.org/1215.htm (stan z 16.03.2008).

${ }^{2}$ IV Sjezd Kommunisticzeskoj Partii Wietnama, Izdatielstwo Politiczeskoj Literatury, Moskwa 1977, s. 458-459.

${ }^{3}$ Overview Association of Southeast Asian Nations, http://www.aseansec.org/64.htm. 
do TAC innym państwom regionu. Protokół stanowi również, że kwestie sporne będą rozwiązywane na drodze dyplomatycznej $\mathrm{w}$ ramach procesów regionalnych, a państwa spoza regionu, które są zaangażowane w konflikt także są do tego zobowiązane. W roku 1998 w Manili 11 państw (w tym Papua Nowa Gwinea) podpisały drugi protokół TAC, w którym znalazły się zapisy wykonawcze do wcześniejszych uzgodnień, określające, że państwa nie będące członkami regionu również mogą podpisać porozumienie.

Ostatnim z tej grupy dokumentów fundamentalnych był Układ o utworzeniu strefy wolnej od broni atomowej w Azji Południowo-Wschodniej (Treaty on the South-East Asia Nuclear Weapon-Free Zone - SEANWFZ), podpisany w roku 1995 w Bangkoku. Podpisali go przedstawiciele 10 państw: Brunei, Filipin, Indonezji, Kambodży, Laosu, Malezji, Myanmaru (Birmy), Singapuru, Tajlandii i Wietnamu, czyli obok starych członków również nowi: Brunei (od 1984), państwa indochińskie: Wietnam (od 1995), Laos i Myanmar (od 1997) oraz Kambodża (od 1999). Strony potwierdziły ważność Układu o nierozprzestrzenianiu broni atomowej ONZ, a w art. VII przywołano prawo „każdej grupy państw do zawierania porozumień regionalnych, dotyczących nierozmieszczania broni atomowej na ich terytorium"4. Chiny i USA potwierdziły wolę respektowania postanowień. Układ SEANWFZ wszedł w życie 27 marca 1997 r. i został poddany negocjacjom z 5 mocarstwami nuklearnymi (w związku z ich przystąpieniem do protokółu, będącego podstawą podpisania Układu). Realizacją celów oraz obsługą adminstracyjną, prawną i finansową (kwestie finansowe i proceduralne zostały określone w Bangkoku w lipcu 2000 r.) zajmuje się Komisja SEANWFZ oraz Komitet Wykonawczy. Dodatkowo lipcowa konferencja ministrów spraw zagranicznych ASEAN ponowiła propozycję skierowaną do mocarstw nuklearnych o podpisanie protokółu Układu o strefie wolnej od broni atomowej w Azji Południowo-Wschodniej ${ }^{5}$.

Ważnym egzaminem dla wypracowanych politycznych form współpracy stała się kwestia zakończenia konfliktu w Kambodży. Inicjatywę przejęła Indonezja, która organizowała dialog między stronami konfliktu, a na nieformalnym spotkaniu w Dżakarcie doszło do rozmów pokojowych między 4 partiami, które miały wypracować platfomę prozumienia narodowego i współpracy. Do procesu pokojowego włączyła się również ONZ i na początku lat dziewięćdziesiątych doszło do zwołania konferencji międzynarodowej z udziałem 19 państw, której współprzewodniczącymi były Francja i Indonezja. 23 października 1991 r. konferencja paryska zakończyła się sukcesem, co otwierało drogę do pokojowego zakończenia konfliktu na Półwyspie Indochiń-

\footnotetext{
${ }^{4}$ Szczegółowe postanowienia Układu patrz: Treaty on the South-East Asia Nuclear WeaponFree Zone, Bangkok, 15 December 1995, www.aseansec.org/2503.htm (stan z 16.03.2008).

${ }^{5}$ D. S in g h, Southeast Asia in 2000, Many Roads, No Destination?, "Southeast Asian Affairs" 2001, s. 5.
} 
skim. 30 kwietnia 1999 r., na konferencji w Hanoi, Kambodża została przyjęta do ASEAN.

Przystapienie Wietnamu, Myanmaru, Kambodży i Laosu do ASEAN zakończyło formowanie organizacji pod względem geograficznym. Obecnie zatem wszystkie państwa regionu Azji Południowo-Wschodniej są jej członkami. Łączy je położenie regionalne i pewne wspólne elementy cywilizacyjne, zbieżność procesów historycznych i strategia gospodarcza. Wciąż jednak pozostało sporo nierozwiązanych problemów, zarówno w relacjach dwustronnych, jak i w szerszym międzynarodowym kontekście, a na stabilność regionu oddziaływują negatywnie etniczne i religijne konflikty wewnętrzne.

Region Azji Południowo-Wschodniej nie jest jednolity pod względem politycznym. Wietnam i Laos są państwami socjalistycznymi, rządzonymi przez partie komunistyczne, w których działalność partii opozycyjnych jest znacznie ograniczona. Myanmar (Birma) jest rządzony autorytarnie, a cechy tej formy sprawowania władzy są widoczne w systemie politycznym Singapuru, gdzie nieprzerwanie rządzi Partia Akcji Ludowej ${ }^{6}$.

Filipiny i Tajlandia są sojusznikami Stanów Zjednoczonych, a ich bezpieczeństwo militarne gwarantuje ten sojusz. Inne państwa regionu mają odmienne doświadczenia z Ameryką, a są to: Laos, Kambodża i Wietnam. Należy przy tym zauważyć, że państwa te unormowały stosunki z USA i rozwijają z nimi współprace gospodarczą.

Państwa tego regionu stanowią mozaikę kulturową i etniczną. W większości z nich dominuje religia buddyjska, choć z różnymi odłamami i specyfiką narodową. Filipiny i Timor Wschodni są państwami chrześcijańskimi, natomiast Brunei, Malezja i Indonezja - islamskimi. W innych, takich jak np. Singapur, Tajlandia i Filipiny, mniejszości muzułmańskie są również znaczące.

Tradycyjnie uznaje się, że państwa Azji Południowo-Wschodniej ukształtowały się i pozostawały pod przemożnym wpływem dwóch wielkich cywilizacji, Chin i Indii, przy czym każde z nich zachowało i utrwaliło swoją specyfikę. W żadnym z hinduistycznych państw: Angkorze, Pagan czy Czampie nie ukształtował się system kastowy, a Wietnam, który w największym stopniu spośród członków ASEAN był poddany wpływom chińskim, zachował własne tradycje i silne poczucie tożsamości narodowej.

Azję Południowo-Wschodnią charakteryzuje o wiele więcej kontrastów, m.in. gwałtowny wzrost liczby mieszkańców miast, prowadzący do pojawienia się ogromnych metropolii, takich jak: Bangkok, Dżakarta, a w latach dziwięćdziesiątych Phnom Penh czy Miasto Ho Chi Minha (Sajgon). Z tym wiążą się różnice między regionami biednymi, nie rozwijającymi się, pozostającymi w stagnacji oraz bogatymi. Przepaść między nimi powiększa się. Przyczyn nierów-

${ }^{6}$ Szerzej na ten temat patrz: J. P o t o c k i, Singapur - azjatycki fenomen. Rozmowa z Goh Chok Tongiem, premierem Singapuru, „Azja-Pacyfik” 2001, nr 4, s. 152-159. 
nomiernego rozwoju należy również szukać w nieumiejętnym zarządzaniu gospodarkami, korupcji, nielegalnych interesach, nepotyzmie, braku przejrzystości gry ekonomicznej. Stąd kryzys finansowy 1997 r. wprowdził takie zamieszanie i jednocześnie wymusił zmiany w funkcjonowaniu mechanizmów ASEAN.

Członkowie ASEAN dostrzegają zagrożenia, wynikające z tej różnorodności, uważają jednocześnie, że dla spójności Stowarzyszenia największym zagrożeniem są różnice gospodarcze między starymi i nowymi członkami (Kambodża, Laos, Myanmar i Wietnam), zwanymi od pierwszych liter nazw angielskich tych państw CLMV. Problem został zdefiniowany w postaci Inicjatywy dla integracji ASEAN (IAI). W roku 2000 wpisano do niej plan na lata 2002-2008, który zakładał przyspieszony rozwój dzięki pomocy zagranicznych inwestorów, fundacji i prywatnych darczyńców ${ }^{7}$.

Regionalizm, widziany przez pryzmat funkcjonowania ASEAN, trzeba widzieć w szerszym kontekście regionu Azji i Pacyfiku. Większość członków Stowarzyszenia należy równocześnie do APEC (Asia-Pacific Economic Cooperation) i to pozwala efektywnie włączać się do procesów globalnych. Obok Unii Europejskiej ASEAN jest najbardziej udaną organizacją regionalnąa ${ }^{8}$.

\section{Kierunki zmian i wizja rozwoju ASEAN}

Inicjatywa zwiększania efektywności instytucji działających w ramach ASEAN pojawiła sie po raz pierwszy w Deklaracji jedności z 24 lutego 1976 r. (Declaration of ASEAN Concord). Deklaracja wyznaczała sfery współpracy: polityczną, ekonomiczną, społeczną, kulturalną i w dziedzinie informacji, bezpieczeństwa oraz doskonalenia mechanizmów funkcjonowania. Postanowiono powołać do życia Sekretariat ASEAN, regularnie monitorować i doskonalić strukturę organizacyjną pod kątem jej efektywności oraz studiować celowość zmian statutowych ASEAN ${ }^{9}$. W czasie kolejnego spotkania w Kuala Lumpur przyjęto decyzję o stałej współpracy z państwami, mającymi wpływ na sprawy regionu, która miała przybrać formę konferencji poministerialnych (Post Ministerial Conference - PMC).

W roku 1982 Stały Komitet ASEAN powołał grupę roboczą pod kierownictwem Anand Panyarachuna z Tajlandii, której zlecono wypracowanie nowych mechanizmów dynamizujących pracę organizacji. Grupa zaproponowała regularne spotkania szefów państw oraz powołanie rady ministrów i stałego

${ }^{7}$ D. E. W e a th e r b e, International Relations in Southeast Asia. The Struggle for Autonomy, Rowman \& Littefield Publishers, 2005, s. 92.

${ }^{8}$ Ibidem, s. 88.

${ }^{9}$ Declaration of ASEAN Concord, Indonesia, 24 February 1976, http://www.aseansec. org/1649.htm (stan z 16.03.2004). 
komitetu na wzór Unii Europejskiej. Ta trzystopniowa struktura, wspomagana przez Sekretariat, miała koordynować pracę ASEAN. W Manili w roku 1987 postanowiono jednak, że spotkania szefów państw nie muszą się odbywać regularnie, a jedynie wówczas, gdy będzie to niezbędne. Druga propozycja zaowocowała utworzeniem Konferencji Wspólnej Ministrów (Joint Ministerial Meeting JMM). Ma ona koordynować politykę zagraniczną i gospodarczą. Oprócz tego formalnymi mechanizmami działania stały się: spotkania wysokich przedstawicieli, ministrów spraw zagranicznych (Senior Officials Meeting - SOM) oraz spotkania wysokich przedstawicieli gospodarczych (Senior Economic Officials Meeting - SEOM), które podlegają JMM. SOM i SEOM, a także dyrektorzy narodowych sekretariatów ASEAN mogą zwoływać spotkania konsultatywne (Joint Consultative Meeting - JCM). Na owe sesje mogą być zapraszane inne odpowiedzialne osoby oficjalne, w zależności od potrzeb. O rezultatach posiedzeń sekretarz generalny ASEAN informuje odpowiednich ministrów.

Jeśli chodzi o sferę gospodarczą, to obok istniejących 5 komitetów: Komitetu Handlu i Turystyki (Committee on Trade and Tourismus - COTT), Komitetu Przemysłu Surowców i Energii (Committee on Industry, Minerals and Energy COIME), Komitetu Finansów i Bankowości (Committee on Finance and Banking - COFAB), Komitetu Żywności i Rolnictwa (Commitee on Food, Agriculture and Foresty - COFAF) oraz Komitet Transportu i Komunikacji (Committee on Transport and Communication - COTAC) zaplanowano utworzenie kolejnych, w tym również na bazie podziału kompetencji dotychczasowych komitetów.

Problemem nadal pozostawała koordynacja prac komitetów oraz brak sprecyzowanych celów narodowych. Brak koordynacji dotyczy ministerstw spraw zagranicznych i gospodarczych oraz samych ministerstw gospodarczych, co stanowi konsekwencję decentralizacji podejmowania decyzji, wielości projektów i inicjatyw. Lekarstwem na ten stan rzeczy miało być zwiększenie efektywności pracy Sekretariatu, któremu przypisano rolę koordynatora. W roku 1992 na kolejnym szczycie zatwierdzono szereg propozycji, zmieniających organizacyjną strukturę Sekretariatu ASEAN, jak również zadecydowano, że szefowie rządów państw członkowskich będą się spotykać co trzy lata. Postanowiono także, że ministrowie gospodarki bardziej aktywnie włączą się do planowania strategii rozwoju kontaków ASEAN z głównymi partnerami handlowymi i partnerami dialogu za pośrednictwem Komitetu Handlu i Współpracy Inwestycyjnej (Trade and Investment Cooperation Committee - TICC). Sekretarz generalny ASEAN jest członkiem, a jednocześnie przewodniczącym Stałego Komitetu ASEAN (ASC). Odpowiada za zwoływanie szczytów i przewodniczący ASC w okresie między szczytami. Pięć dotychczasowych komitetów ekonomicznych zostało rozwiązanych, a ich kompetencje przejął SEOM.

Kolejną inicjatywą ASEAN stało się wyłonienie grupy wybitnych profesjonalistów (Eminent Persons Group), którym powierzono opracowanie wizji 
ASEAN do 2020 r. Wyłoniona w ten sposób East Asia Vision Group (EAVG), przekształcona w roku 2000 w East Asia Study Group (EASG), złożona z przedstawicieli ASEAN oraz Chin, Japonii i Korei Południowej) za najważniejsze zadania uznała utworzenie do 2020 r. strefy wolnego handlu (East Asia Free Trade Area - EAFTA) ${ }^{10}$ w całej Azji Wschodniej, liberalizację handlu i ekspansję inwestycyjną (ASEAN Investment Area - AIA) na całą Azję Wschodnią, promocję rozwoju technologicznego, szczególnie z udziałem słabiej rozwiniętych państw oraz gospodarki opartej na wiedzy ekonomicznej. Innym rekomendowanym przez EASG przedsięwzięciem było rozwijanie ASEAN $+3^{11}$.

Nadrzędną idea, która przyświecała tej inicjatywie było uczynienie z ASEAN organizacji dynamicznej i kompetentnej, tak, aby region Azji Południowo-Wschodniej z powodzeniem mógł sprostać współczesnym tendencjom globalistycznym. Ponadto podkreślono, że jej celem jest wyłonienie społeczeństw obywatelskich - planowane zakończenie tego prcesu ma nastąić w perspektywie 20 lat $^{12}$.

Hanojski plan działania (Hanoi Plan of Action) przyjęto 15 grudnia $1998 \mathrm{r}$. i jest to początek realizacji wizji ASEAN 2020, przyjętej w Kuala Lumpur w roku $1997^{13}$. Plan hanojski był przewidziany do realizacji w okresie 19992004. Nakreślono w nim konkretne przedsięwzięcia w następujących dziedzinach, współpraca makroekonomiczna i finansowa, umocnienie integracji gospodarczej, promocja nauki, techniki i infrastruktury technologiczno-komunikacyjnej w sferze społecznej (ze szczególnym uwzględnieniem przezwyciężania skutków kryzysu finansowego, rozwoju zasobów ludzkich, ochrony środowiska, umacniania bezpieczenstwa regionalnego i pokoju), wzmocnienie pozycji regionu w świecie, podniesienie roli sił pokojowych, doskonalenie struktury organizacyjnej, których celem jest zwiększenie efektywności: ekspansja ASEAN, większa aktywność, wpływ na rozwój stosunków regionalnych, także poprzez system dialogu z państwami trzecimi, organizacjami regionalnymi i grupami gospodarczymi.

ASEAN zamierza zmodernizować pracę Sekretariatu zgodnie z planem hanojskim. Nabardziej rozbudowana jest część odnosząca się do integracji regionalnej. Podstawowym zadaniem, jakie sobie wyznaczono, jest przyspieszenie procesu tworzenia strefy wolnego handlu AFTA. W związku z tym szczegółowo

\footnotetext{
${ }^{10}$ Decyzję o utworzeniu strefy wolnego handlu ASEAN (AFTA) podjęto w roku 1992 i zaczęła funkcjonować 1 stycznia 1993 r. Wówczas członkami ASEAN było 6 państw. Realizacja porozumień dwustronnych i wielostronnych dla niektórych państw jest zakończona, dla innych w toku.

${ }^{11}$ Peng-Hong Cai, East Asian New Regionalism And China, http://www.cepii.fr/anglaisgraph/communications/pdf/2006/09100206/PengHong.pdf.

${ }^{12}$ Report of the ASEAN Eminent Persons Group (EPG) on Vision 2020: The People Bangkok, Thailand, 24-25 July 2000, www.aseansec.org.

${ }^{13}$ ASEAN Vision 2020, http://www.asensec.org/2357.htm (stan z 16.03.2004).
} 
rozpisano procedury, które muszą ulec zmianie, aby umożliwić realizację tego zadania. Ponadto, aby zwiększyć konkurencyjność regionu, postanowiono wprowadzić wszelkie ułatwienia inwestycyjne w ramach porozumienia AIA, a także takie, które miałyby służyć ułatwieniom w dziedzinie współpracy technologicznej, handlowej, małych i średnich przedsiębiorstw, turystyce, tworzeniu infrastruktury, w tym dróg, gospodarki wodnej i innych. Taka wizja regionu sprzyjałaby wytworzeniu odpowiedzialności, opartej na wspólnej historii, tożsamości kulturowej, przy zachowaniu narodowej odrębności, języka, religii podstaw społecznych i kulturowych ${ }^{14}$.

Kolejnym etapem realizacji wizji ASEAN 2020 było przyjęcie 7 października 2003 r. w Bali Deklaracji jedności II (Bali Concord II), która odwołuje się do wcześniejszych porozumień podpisanych przez ASEAN: Deklaracji ASEAN z 1967 r., Deklaracji ZOPFAN z 1971 r., TAC z 1976 r., Deklaracji jedności z 1976 r. oraz SEANWFZ z 1995 r. Porozumienie wymienia 3 filary współpracy: wspólnotę bezpieczeństwa (ASEAN Security Community - ASC), wspólnotę gospodarczą (ASEAN Economic Community - AEC) oraz wspólnotę społeczno-kulturową (ASEAN Socio-Cultural Community - ASCC). Zakłada oparcie bezpieczeństwa na ściślejszych relacjach i gospodarczych więzach w regionie. W części dotyczącej bezpieczeństwa państwa potwierdziły suwerenne prawo każdego członka Stowarzyszenia do formułowania takiej strategii polityki zagranicznej i obrony, która jest zgodna $\mathrm{z}$ realiami politycznymi, ekonomicznymi, społecznymi i opiera się raczej na dialogu niż na paktach miltarnych, sojuszach czy wspólnej polityce zagranicznej. W tym kierunku Stowarzyszenie miało rozwijać współpracę z państwami dialogu. Wzmacniając bezpieczeństwo ASEAN ma wykorzystywać instrumenty prawne, prewencyjne, prowadzić dialog oraz oferować pomoc w ,zaleczeniu ran” po konfliktach.

Dla Indonezji problemy bezpieczeństwa są bardzo istotne, dlatego też powołanie ASC wiąże się z zaangażowaniem Dżakarty. Impulsem dla tej inicjatywy stała się walka z terroryzmem i przestępczością międzynarodową. Dżakarta występuje jako centrum strategiczne bezpieczeństwa regionalnego i jest inicjatorem powołania w regionie sił pokojowych. Propozycja padła 21 lutego $2004 \mathrm{r}$. na spotkaniu 10 członków ASEAN. Stanowi jedną z kilku sformułowanych przez Indonezję i ma służyć realizacji ASC do 2020 r. Pytanie stawiane w związku z przyszłością sił pokojowych w tym regionie jest następujące: czy siły te winny działać jedynie w wymiarze regionalnym czy też współpracować z ONZ i koordynować wspólne treningi oraz szkolenia w grupie państw ASEAN. Indonezyjska inicjatywa nie oznacza utworzenia paktu militernego czy też obronnego, lecz działania w oparciu o już istniejące ZOPFAN, SEANWFZ oraz TAC. Działalność w ramach ARF (ASEAN Regional Forum) stwarza szersze możliwości współpracy z innymi partnerami regionalnymi.

\footnotetext{
${ }^{14}$ Ibidem.
} 
Innymi propozycjami zgłoszonymi przez Indonezję były: układ o nieagresji, porozumienie o ekstradycji oraz konwencja dotycząca walki z terroryzmem i rejestracji armii. Plan indonezyjski omawiano w Hanoi 3-5 marca 2004 r. ${ }^{15}$

Jeśli chodzi o drugi filar, czyli AEC, to w dziedzinie gospodarczej zwrócono uwagę na konkurencyjność w gospodarce globalnej, a zatem: swobodny przepływ dóbr, usług, inwestycji, kapitału, równomierny rozwój, likwidację sfery ubóstwa i dysproporcji społeczno-ekonomicznych zgodnie z wizją ASEAN 2020. Podkreślono konieczność doskonalenia już istniejących mechanizmów, porozumienia na temat usług (ASEAN Framework Agreement on Services AFAS) oraz obszaru inwestycyjnego (ASEAN Investment Area - AIA), natomiast nowym elementem miało być tworzenie ciała zajmującego się ściślejszą integracją gospodarczą ASEAN (High Level Task Force on ASEAN Economic Integration). Państwami najbardziej zainteresowanymi rozwojem współpracy w ramach AEC są Singapur oraz Tajlandia; widzą one rosnąca konkurencję ze strony Indii oraz Chin ${ }^{16}$.

Trzeci filar, czyli współpraca w dziedzinie społeczno-kulturalnej (ASCC), zakłada współdziałanie w dziedzinie opieki medycznej, szkolnictwa (np. szkolenie nauczycieli), rozwiązywanie wspólnych problemów: bezrobocia, zanieczyszczenia środowiska, eksplozji demograficznej itp. ${ }^{17}$ Znawcy problematyki twierdzą, że być może współpraca w ramach ASCC stanie się najbardziej efektywana i możliwa do realizacji. Już dzisiaj funkcjonują liczne inicjatywy, np. plan w dziedzinie rozwoju wsi i likwidacji biedy (ASEAN Plan of Action on Rural Development and Pover Eradication), plan dotyczący opieki społecznej i rozwoju (ASEAN Work Programme on Social Welfare and Development) oraz bezpieczeństwa społecznego (ASEAN Action Plan on Social Safety Nets) ${ }^{18}$. Ta sfera działalności uaktywnia społeczeństwa regionu. Liczne organizacje pozarządowe są wspierane przez agencje, takie jak: USAID, NZAID, AUSAID czy też UNDP, UNICEF, WHO. W ramach Deklaracji Jedności II członkowie ASEAN zobowiązali się żyć $\mathrm{w}$ pokoju $\mathrm{z}$ wszystkimi państwami, a dokument potwierdza zasady nieingerencji $\mathrm{w}$ sprawy wewnętrzne $\mathrm{i}$ zasadę konsensusu w podejmowaniu decyzji.

W drugiej połowie lat dziewięćdziesiątych uaktywniły się w ramach ASEAN subregiony. Do nich można zaliczyć: trójkąt Indonezja-Malezja-Singapur, Indonezja-Malezja-Tajlandia, Brunei-Indonesja-Malezja-Filipiny (East ASEAN Growth Area) oraz Wielki Subregion Mekong. W ramch tego ostatniego można wyróżnić tworzący się trójkąt Laos-Wietnam-Kambodża. Inicjatywy subregionalne wspiera Azjatycki Bank Rozwoju (ADB).

${ }^{15}$ Indonesia proposes ASEAN peacekeeping force, http://www.inq7.net/brk/2004/ feb/21/brkafp_4-1.htm.

${ }^{16}$ D. E. W e a th e r b e e, op. cit., s. 108.

${ }^{17}$ Declaration of ASEAN Concord II (Bali Concord II), http://www.asensec.org/15160.htm.

${ }^{18}$ D. E. W e a th e r b e e, op. cit., s. 109. 


\section{ASEAN a spory i konflikty w regionie}

Jak było powiedziane, ASEAN realizuje nie tylko cele gospodarcze. Ważnym obszarem działności są kwestie stabilności i bezpieczeństwa $\mathrm{w}$ regionie. Stowarzyszenie reaguje na wszystkie te zjawiska, które mogą stanowić zagrożenie dla bezpieczeństwa. Do nich należały m.in.: konflikt terytorialny na Morzu Południowo-Chińskim, problem samostanowienia Timoru Wschodniego oraz zamieszki w Indonezji, wynikające z konfliktów na tle etnicznym i religijnym. $\mathrm{Na}$ stosunkach Tajlandii z niemal wszystkimi sąsiadami: Laosem, Kambodżą i Myanmarem ciążą zaszłości historyczne, których państwa te do chwili obecnej nie rozwiązały. Również stosunki bilateralne Singapuru i Malezji obarczone są sporami, będącymi konsekwencją separacji z 1965 r. Strony odwoływały się już do rozstrzygnięć Międzynarodowego Trybunału Sprawiedliwości i Stałego Sądu Arbitrażowego, nadal jednak rozstrzygnięcia tych instancji nie zostały zrealizowane. Nierozstrzygnięty pozostaje spór malezyjsko-filipiński o stan Sabah w Północnym Borneo. Utrzymuje się konflikt między Malezją a Indonezją o dwie wysepki: Ligitan i Sipidan, leżące na północnym wybrzeżu Borneo.

Spośród wymienionych sporów i konfliktów w regionie Azji Południowo-Wschodniej najwięcej uwagi poświęcono konfliktowi terytorialnemu na Morzu Południowo-Chińskim, ponieważ dotyczy on największej grupy państw. Temat konfliktu podjęto już w Manili, gdzie w roku 1992 wynegocjowano deklarację, w której zaproponowano modus vivendi i postanowiono, że będzie on rozwiązany środkami pokojowymi, bez użycia przemocy. Chiny i członkowie ASEAN mieli wypracować system zachowań i zarządzania spornymi wyspami Spratly i Paracelskimi. Udało się osiaggnąć postęp i w roku 2002 przyjęto Deklarację o postępowaniu w rejonie Morza Południowo-Chińskiego. Strony zobowiązały się w niej do niepodejmowania żadnych działań siłowych lub pod groźbą użycia siły, lecz działać na drodze przyjacielskich konsultacji i negocjacji suwerennych państw, na podstawie zasad prawa międzynarodowego, włączając w to Konwencję ONZ z 1982 r. Do czasu pokojowego rozstrzygnięcia strony zobowiązały się utrzymywać dialog i wymieniać poglądy na tematy obrony, zagrożeń, chronić ludzi przed niebezpieczeństwami, wymieniać się na zasadzie wzajemności odpowiednimi informacjami. Natomiast w kwestii gospodarki morskiej zapadły decyzje dotyczące ochrony środowiska, wspólnych badań naukowych, chronienia nawigacji i komunikacji morskiej, a ponadto walki z przestępczością morską, transportem narkotyków itd. ${ }^{19}$

W sprawie Timoru Wschodniego ASEAN monitorował i konsultował realizację porozumień, podpisanych między Indonezją a Portugalią oraz między ONZ a rządami Indonezji i Portugalii z 5 maja 1999 r. ASEAN zadeklarował poparcie dla Timoru Wschodniego w jego dążeniach do osiagnięcia pełnej

\footnotetext{
${ }^{19}$ Declaration on the Conduction in the South China Sea, www.asensec.org/13163.htm.
} 
niepodległości i zaoferował pomoc, a jednocześnie potwierdził poszanowanie terytorialnej integralności Indonezji.

Obok sporów terytorialnych, w kwestii bezpieczeństwa dla ASEAN ważne są również: problemy nierozprzestrzeniania broni masowego rażenia $\mathrm{w}$ regionie oraz następstwa procesów globalizacji i terroryzmu. Potencjalnymi zagrożeniami dla stabilności są także stosunki na Półwyspie Koreańskim oraz relacje Chiny-Tajwan. Włączenie Korei Północnej do ARF było również formą poparcia dla ewolucyjnego zbliżenia obu rozdzielonych państw koreańskich i wzmocnienia bezpieczeństwa w tej części Azji. ASEAN z zadowoleniem odnotował historyczne spotkanie przywódców obu Korei w Pyongyang w dniach 13-15 czerwca $2000 \mathrm{r}$.

Niewątpliwie najbardziej niebezpiecznym zjawiskiem ostatniego okresu dla wszystkich państw tego regionu jest terroryzm, dlatego w tych kwestiach działalność ASEAN jest szczególnie widoczna. Ataki terrorystyczne na Bali w Indonezji i na Filipinach w miejscowościach Zamboanga i Quezon zostały potępione, a w czasie 8. szczytu ASEAN, który odbywał się w Phnom Penh (listopad 2002) przyjęto deklarację na temat zwalczania terroryzmu. Państwa ASEAN potępiły terroryzm jako sposób walki o indywidualne prawa oddzielnych grup etnicznych i religijnych. W listopadzie 2001 r. w Brunei (Darussalam) przyjęto deklarację dotyczącą wspólnych akcji antyterrorystycznych, wystosowano również list do sekretarza stanu USA, Collina Powela, w sprawie ataków terrorystycznych. Pozostałe inicjatywy, związane $\mathrm{z}$ utworzeniem wspólnego frontu antyterrorystycznego to konferencje w Manili (listopad 2002) i na Bali (grudzień 2002), deklaracje: na temat zwalczania terroryzmu, przyjęta na szczycie ASEAN w Phnom Penh (3 listopada 2002 r.), o dzień później Chiny ASEAN na temat współpracy w dziedzinie bezpieczeństwa; wspólna deklaracja przyjęta w Brukseli na 14. konferencji ministerialnej ASEAN-UE (27 stycznia 2003), ARF w Malezji (Kota Kinabalu) w marcu 2003 r., konferencja z Chinami, Japonią i Koreą (ASEAN + 3) w Bangkoku, w czasie której uzgodniono wspólny komunikat (10 stycznia 2004), konferencja szefów policji (16-20 sierpnia 2004) w Chiang Mai w Tajlandii i powstanie w listopadzie $2002 \mathrm{r}$. regionalnego centrum walki z terroryzmem w Kuala Lumpur.

\section{ASEAN-ARF}

Region jest teatrem wpływów 5 mocarstw: Chin, Japonii, Rosji, Indii i USA, z czego 4 są mocarstwami nuklearnymi. Poczucie bezpieczeństwa w tym regionie obniżają wymienione wcześniej rozliczne konflikty, historyczne animozje, niekiedy rywalizacja i nieufność między uczestnikami systemu, mimo znacznych postępów, które się w tej sferze dokonały. 
Inicjatywą, która miała poprawić ten stan rzeczy było powołanie do życia w roku 1993, na 26. konferencji AMM w Singapurze, Regionalnego Forum ASEAN (ASEAN Regional Forum - ARF). Pierwsze spotkanie miało miejsce rok później - w Bangkoku ${ }^{20}$.

W lipcu 1996 r. ARF przyjęło następujące kryteria członkostwa:

- członkami mogą zostać suwerenne państwa, które zobowiążą się do respektowania celów ARF i wszystkich podjętych wcześniej decyzji; członkowie ASEAN stają się automatycznie członkami ARF;

- członkostwo mogą uzyskać tylko te państwa, które są ważne dla sprawy pokoju i bezpieczeństwa w regionie (np. pod względem bliskości geograficznej);

- forum będzie stopniowo powiększane, aby kontrola nad członkami była bardziej efektywna;

- każda nowa kandydatura będzie przedstawiana przewodniczącemu ARF, mającym obowiązek konsultowania jej ze wszystkimi nowymi członkami ${ }^{21}$.

Zatem, z założenia, członkami ARF są państwa zrzeszone w ASEAN, ale oprócz tego - partnerzy poministerialnego dialogu: Stany Zjednoczone, Australia, Japonia, Nowa Zelandia, Kanada, Republika Korei, Papua Nowa Gwinea (obserwator ASEAN), Chiny i Rosja (partenrzy dialogu, zaproszeni specjalnie), Indie (partner dialogu od 1996 r.), Mongolia (od 1999 r.), Ludowo-Demokratyczna Republika Korei (od 2000 r.), Unia Europejska, Timor Wschodni, Pakistan oraz Bangladesz. Sri Lanka została przyjęta do ARF w roku 2007.

Powołanie ARF zbiegło się w czasie z zakończeniem okresu zimnowojennego i koniecznością wypracowania nowych form współpracy i bezpieczeństwa międzynarodowego. Oparto je na trzech zasadach: dyplomacji prewencyjnej, przeciwdziałaniu konfliktom i budowie środków wzajemnego zaufania. Planowaną działalność podzielono na trzy etapy. Etap pierwszy, polegający na budowie środków wzajemnego zaufania, zakładał w pierwszej kolejności oparcie się na doświadczeniach ASEAN: redukcji napięcia między członkami organizacji, rozwoju współpracy, stworzeniu sprzyjającego klimatu międzynarodowego i warunków odpowiednich do utrzymania pokoju i stabilności w regionie. Tak postawione cele wkomponowano w podjęte już wcześniej inicjatywy: Porozumienie o Utworzeniu Strefy Pokoju, Wolności i Neutralności (ZOPFAN), podpisane w 1971 r., Układ o Przyjaźni i Współpracy w Azji Południowo-Wschodniej (TAC) z 1976 r. i Układ o utworzeniu Strefy Wolnej od Broni Atomowej w Azji Południowo-Wschodniej (SEANWFZ) z roku 1995.

W takiej strukturze TAC jest formą legalizacji współpracy, a SEANWFZ komponentem militarnym. Wszystkie trzy formy stanowią filary, na których

${ }^{20} \mathrm{Na}$ temat ARF patrz również: E. H a li ż a k, Stosunki międzynarodowe $w$ regionie Azji i Pacyfiku, Wydawnictwo Naukowe Scholar, Warszawa 1999, s. 419-424.

${ }^{21}$ Overview Association... 
opiera się bezpieczeństwo w regionie Azji Południowo-Wschodniej ${ }^{22}$. Fazą drugą, którą zakłada ARF, jest rozwój dyplomacji prewencyjnej, natomiast trzecią, najtrudniejszą i wybiegającą $w$ przyszłość, jest stworzenie mechanizmów zapobiegających konfliktom w regionie. ARF nadal pozostaje w fazie pierwszej. W ostatnim okresie zorganizowano szereg spotkań w ramach Grupy Budowy Środków Zaufania (Group on Confidence Building Measures). Jej ideę stanowi współprzewodniczenie sesjom przez członków oraz państwa, nie będące członkami ASEAN. W latach 2003-2004 były to Chiny i Myanmar, w latach 2004-2005 - UE i Kambodża. Na konferencjach zajmujących się problemami terroryzmu i przestepczości transnarodowej w latach 2003-2004 współprzewodniczącymi były Malezja i USA, w 2004-2005 Filipiny i Rosja, a w 2005-2006 Kanada i Tajlandia ${ }^{23}$.

Oprócz tych tradycyjnych mechanizmów ARF dąży do stworzenia nowych, które przede wszystkim służyłyby dyplomacji prewencyjnej. Koncepcja dyplomacji prewencyjnej została wypracowana w roku 2001. Zadaniom tym poświęcone są badania centrów naukowych: International Studies Center (w Tajlandii), Institute Policy Studies (w Singapurze) oraz koordynowane przez Indonezję badania dotyczące Morza Południowo-Chińskiego. Przy ASEAN działa również Instytut Studiów Strategicznych i Międzynarodowych (ISIS).

Do tej pory członkom ARF udało się wypracować takie formy współdziałania, jak: wzajemne informowanie się o doktrynach wojennych, wydawanie białych ksiag, dotyczących problematyki obronnej, wymiana studentów uczelni wojskowych i obserwatorów między ministerstwami obrony, powstanie gorących linii, zawiadamianie o wielkich manewrach wojskowych, utworzenie centrum, zajmującego się przeciwdziałaniu konfliktom i inne. Nową formą współpracy w zakresie bezpieczeństwa są Asian Senior-levels Talks on Proliferation (ASTOP), które odbywają się w Tokio. Uczestniczą w nich przedstawiciele ASEAN, Australii, Chin, Republiki Korei, USA, którzy dyskutują nad problemami nierozprzestrzeniania broni masowego rażenia (WMD). Pierwsze z takich spotkań odbyło się w listopadzie $2003 \mathrm{r}^{24} \mathrm{~W}$ ostatnim, do którego doszło w styczniu 2007 r., po raz pierwszy uczestniczyły delegacje Kanady i Nowej Zelandii; omawiane były zagrożenia związane $\mathrm{z}$ irańskimi i koreańskimi próbami nuklearnymi.

Z kolei konferencja ARF w Manili, zorganizowana w maju 2007 r., została poświęcona stworzeniu warunków większej odpowiedzialności za bezpieczeństwo, ,zmobilizowaniu grup ekspertów”. W tym czasie najważniejszą kwestią

${ }^{22}$ Na podstawie: C. P. F. L u h u 1 i m a, Scope of ASEAN's Security Framework for the $21^{\text {st }}$ Century, Singapore 2000.

${ }^{23}$ D. E. W e a th e r b e e, op. cit., s. 150.

${ }^{24}$ T. O g i l v i e-Wh it e, Non-Proliferation and Counterterrorism Cooperation in Southeast Asia: Meeting Global Obligations Through Regional Security Architectures, „Contemporary Southeast Asia" 2006, Vol. 28, Iss. 1, www.questia.com. 
były sześciostronne rozmowy w sprawie Korei Północnej. W wyniku dyskusji sformułowano wniosek, że ARF jest mało mobilne - spotyka się raz w roku i omawia problemy globalne, tymczasem należy tworzyć mniejsze grupy, które mogłyby szybciej reagować na konkretne zagrożenia ${ }^{25}$. Problemem, który rzeczywiście można dostrzec w działaności ARF jest jego mała efektywność, hasłowe reagowanie na zagrożenia.

\section{ASEAN i zinstytucjonalizowane formy dialogu z państwami trzecimi}

Strategia ASEAN jest wzmocnienie regionalizmu. Taki cel przyświeca również współpracy z państwami lub grupami państw, które są ważne z punktu widzenia interesów Stowarzyszenia. Decyzję o zintensyfikowaniu tego typu działalności podjęto na drugim szczycie w Kuala Lumpur w roku 1976 i już wóczas stała się ona podstawą do rozmów z premierami Australii, Nowej Zelandii i Japonii. W następnym roku po raz pierwszy odbyła się konferencja poministerialna (PMC), która od tej pory stała się formą dialogu z państwami nie będącymi członkami ASEAN. Oprócz tego między konferencjami odbywają się różnego typu spotkania, służące pogłębianiu współpracy.

ASEAN podjął zinstytucjonalizowane formy współpracy (pełny lub niepełny - sektorowy dialog) z wszystkimi państwami i organizacjami, których głos w sprawach regionu jest znaczący. Są to: ASEAN + 3 (Chiny, Japonia, Korea Południowa), ASEAN + Australia, Kanada, Chiny, UE, Indie, Japonia, Korea, Nowa Zelandia, Rosja, USA, Pakistan, UNDP. Formy współpracy z wymienionymi państwami czy organizacjami są różne, np. ze Stanami Zjednoczonymi ASEAN współpracuje od 1977 r. na zasadzie wzajemnych konsultacji, głównie w dziedzinie gospodarki, wymiany handlowej i finansów. Po okresie zimnej wojny konsultacje coraz częściej dotyczą problemów pokoju i bezpieczeństwa, a ASEAN traktuje obecność USA w regionie jako czynnik stabilizujący, równoważący wpływy Chin. Siły amerykańskie są potrzebne zwłaszcza w obliczu potencjalnego konfliktu tajwańskiego oraz koreańskiego. Ekipa prezydenta Busha większą wage przywiązuje do nieco pozostawionego z boku przez Billa Clintona sojuszu z Japonią. Niechęć budzą natomiast unilateralizm amerykański, walka o prawa człowieka i demokratyzację, nie zawsze zgodną z koncepcjami azjatyckimi, a ponadto brak widocznej pomocy w przezwyciężaniu kryzysu finansowego. Niektórzy politycy mieli nadzieję, że Stany Zjednoczone podejmą jakieś akcje, podobnie jak w Meksyku, ale Amerykanie tego nie zrobili. Demonstarcje przeciw Ameryce rozpoczęły się w Indonezji jeszcze przed 11 marca 2001 r. Stosunek do USA jest zróżnicowany - Japonia, Południowa Korea, Tajlandia i Filipiny są sojusznikami USA, a ich bezpieczeństwo opiera się na

${ }^{25}$ ARF officials to discuss ways to make ARF "more responsive" Asian Political News, www.findarticles.com/p/articles/mi_OWDQ/is_2007_May_28/ai_n19172783-31k. 
tym sojuszu. Również Singapur utrzymuje ścisłe relacje z USA, natomiast Chiny i państwa indochińskie mają inne doświadczenia.

Ataki terrorystyczne w USA spowodowały zbliżenie stanowisk odnośnie do terroryzmu i konieczności jego zwalczania. 1 sierpnia 2002 r. w Bandar Seri Begawan podpisano wspólną deklarację $\mathrm{w}$ tej sprawie i dodatkowo Stany Zjednoczone zapowiedziały nowe inicjatywy związane ze współpracą z ASEAN w dziedzinie informacji i technologii, biotechnologii, zdrowia, klęsk żywiołowych oraz w sferze organizacyjnej (pracy Sekretariatu).

Dialog ASEAN-Rosja datuje się od 1991 r., kiedy po raz pierwszy wzięła ona udział w spotkaniu konsultatywnym. W roku 1993, na 26. szczycie AMM (ASEAN Ministerial Meeting), minister spraw zagranicznych Rosji wyraził chęć zinstytucjonalizowania wzajemnych relacji. Rosja została zaproszona do członkostwa w ARF. W roku 1995 w Moskwie odbyło się seminarium ARF, dotyczące zasad bezpieczeństwa i stabilności w regionie Azji i Pacyfiku. W roku 1996 Rosja uzyskała status pełnoprawnego partnera dialogu ASEAN ${ }^{26}$, a w rok później, w Dżakarcie, miało miejsce pierwsze forum biznesu Rosji z Izbą Handlu i Przemysłu (Chamber of Commerce and Industry - CCI). W kwietniu 2002 r. odbyło się w Moskwie spotkanie oficjalnych przedstawicieli ASEAN i Rosji na temat współpracy dwustronnej i wielostronnej w walce $\mathrm{z}$ terroryzmem, przestępczością zorganizowaną i przemytem narkotyków ${ }^{27}$. Tak więc zinstytucjonalizowane formy, w których Rosja bierze udział, to konferencje konsultatywne z udziałem ARF, Post Ministerial Meeting (PMC) i Wspólny Komitet Współpracy ASEAN-Rosja (JCC).

Współpraca z ASEAN jest wyrazem aktywizacji polityki azjatyckiej Rosji przez prezydenta Wladimira Putina, zwłaszcza wobec dawnych sojuszników, czego wyrazem były wizyty w Indiach i Mongolii w roku 2000 i podpisanie nowych porozumień militarnych ${ }^{28}$. W marcu 2001 r. cały pakiet zagadnień związanych $\mathrm{z}$ bezpieczeństwem militarnym i współpracą międzynarodową został omówiony w czasie wizyty na najwyższym szczeblu prezydenta Wladimira Putina w Hanoi ${ }^{29}$. W maju 2004 r. w Moskwie był prezydent Socjalistycznej Republiki Wietnamu Tran Duc Luong i wówczas utworzono Forum Biznesu Rosyjsko-Wietnamskiego. Rosja zaczęła aktywizować swoją politykę wobec Malezji. Premier Mohathir skrytykował inwazję wojsk amerykańskich na Irak. Krytyka USA zbliżyła oba państwa. Rozpoczęła się współpraca wojskowa

${ }^{26}$ Szerzej na temat miejsca i roli Rosji w systemie bezpieczeństwa regionu Azji i Pacyfiku patrz: W. W. S a m o j 1 i e n k o, Mnogostaronnaja diplomatija $w$ ATR $w$ obłasti obiespieczenija bezopasnosti i uczastieje w niej Rosii, http://isn.rsuh.ru/icis/atrsec/assam.htm.

${ }^{27}$ ASEAN-Russia Dialogue, http://www.aseansec.org/5922.htm.

${ }^{28}$ D. S i n g h,op. cit., s. 23.

${ }^{29}$ Szerzej na temat stosunków rosyjsko-wietnamskich patrz: M. P i e tra s i a k, Stosunki wietnamsko-rosyjskie $w$ okresie modernizacji systemu społeczno-ekonomicznego Wietnamu, „Stosunki Międzynarodowe” 2002, nr 1-2, s. 189-202. 
(handel bronia), rozwinęła się też współpraca $\mathrm{w}$ tej dziedzinie z Indonezją i Tajlandią.

ASEAN i Rosję interesuje współpraca głównie w dziedzinach nauki i technologii, turystyki, kultury i kontaktów międzyludzkich. 13 grudnia 2005 r. odbył się pierwszy szczyt ASEAN-Rosja w Kuala Lumpur. W czasie spotkania przyjęto program współpracy na lata 2005-2015, włączając w to wzajemne informowanie się o zagrożeniach terrorystycznych oraz potencjale broni masowego rażenia ${ }^{30}$. Rosja została również zaproszona przez Malezję na pierwszy szczyt East Asian Summit (EAS) i uczestniczyła w nim w charakterze obserwatora.

Chiny zinstytucjonalizowały dialog z ASEAN w tym samym czasie co Rosja. Rozwijają one kontakty z państwami regionu Azji Południowo-Wschodniej raczej w oparciu o stosunki bilateralne, ale przełomem były wydarzenia na Placu Tiananmen (1989 r.), kiedy Chiny zdecydowały się również wzmacniać mechanizmy wielostronne. Pierwsze nieformalne kontakty rozpoczęły się w roku 1991, kiedy chiński minister spraw zagranicznych Qian Qichen uczestniczył w 24. AMM w Kuala Lupur. W roku 1994 strony wymieniły oficjalne pisma w tej sprawie, a na 29. konferencji na szczycie w Dżakarcie w roku 1996 Chiny otrzymały status pełnoprawnego partnera dialogu i utworzono komitet współpracy. ASEAN podjął dialog $\mathrm{z}$ tym państwem również $\mathrm{w}$ ramach współpracy ASEAN + 3 (Chiny, Japonia, Korea Południowa). Wzajemne konsultacje dotyczą tematów bezpieczeństwa i współpracy politycznej. W kwietniu $2001 \mathrm{r}$. w Pekinie odbyła się konferencja ekspertów ds. współpracy gospodarczej obu stron, która zajmowała się rozwojem stosunków gospodarczych w XXI w. Premier Zhu Rongji, który uczestniczył w szczycie ASEAN w Phnom Penh w 2002 r., podkreślił znaczenie, jakie jego rząd przywiązują do współpracy w ramach tej instytucji ${ }^{31}$. Podpisano porozumienie o współpracy gospodarczej ASEAN - Chiny, którego cześcią ma być ustanowienie strefy wolnego handlu do 2010 r. ze starszymi członkami i do 2015 z nowymi. Możliwość ustanowienia strefy wolnego handlu ASEAN-Chiny zarysowała się po wstapieniu Chin do WTO (stało się to po 15 latach negocjacji, 10 grudnia $2001 \mathrm{r}$.). Ważne miejsce $\mathrm{w}$ rozmowach zajęły tematy związane $\mathrm{z}$ bezpieczeństwem $\mathrm{w}$ regionie Azji Południowo-Wschodniej. Pekin wyraził gotowość przystapienia do Układu o przyjaźni i współpracy w Azji Południowo-Wschodniej oraz współpracy w ramach strefy wolnej od broni atomowej w Azji Południowo-Wschodniej.

W styczniu 2004 r. ASEAN podpisał memorandum o wzajemnym zrozumieniu z Chinami, dotyczące współpracy w dziedzinie ścigania przestępstw oraz

${ }^{30}$ L. B o szyński, Russia and Southeast Asia: A new Relationship, „Contemporary Southeast Asia” 2006, Vol. 28, Iss. 2.

${ }^{31}$ ASEAN and China, http://www.mfaic.gov.kh/ASEAN\%20Summit/Background\%20Pa.../ ASEAN-China.html. 
przestępczości międzynarodowej. Do nowych zjawisk w tym zakresie zaliczono: terroryzm, pranie brudnych pieniędzy, cyberprzestępstwa (cyberterroryzm), międzynarodowe przestępstwa gospodarcze. W memorandum jest także mowa o handlu narkotykami, handlu żywym towarem, piractwie, nielegalnym handlu bronią $^{32}$. Problem ten był również omawiany w czasie spotkania ministrów spraw zagranicznych ASEAN $+3 \mathrm{w}$ Bangkoku, a tajski minister sprawiedliwości Phongthep Thepkanjana stwierdził, że jest to dowód na myślenie w kategoriach dobra całego regionu Azji Wschodniej. Chiny sa także aktywnym członkiem ARF i wysunęły nawet ideę koordynacji polityki bezpieczeństwa i polityki zagranicznej w ramach partnerstwa strategicznego.

Opierając się na badaniach Kuik Cheng-Chwee, które opublikował w artykule o multirateralizmie w chińskiej polityce wobec ASEAN ${ }^{33}$, kontakty między ChRL a tą organizacją można podzielić na 3 fazy: pierwsza to lata 1990-1995, polegająca na włączaniu się do współpracy, druga obejmuje okres 1996-1999 (aktywne uczestnictwo), natomiast trzecia - okres współczesny (wysuwanie nowych propozycji, które stawiają Chiny w gronie aktywnych graczy $\mathrm{w}$ regionie). Do tych inicjatyw należy przede wszystkim stworzenie strefy wolnego handlu (ASEAN-China Free Trade Area - ACFTA). Realizacja tego planu pomoże Chinom w realizacji innych dalekosiężnych planów gospodarczych i politycznych. Wśród tych pierwszych można wymienić pozyskiwanie źródeł energii, drugie to rozwiązanie problemu wysp na Morzu Południowo-Chińskim, pozyskanie poparcia dla multirateralizmu w stosunakch międzynarodowych oraz powrót do tradycyjnych regionów wpływu ${ }^{34}$.

ASEAN od 1977 r. współpracuje z Japonią. Przełomowy moment w polityce regionalnej Japonii stanowiła doktryna Fukudy z roku 1977, kiedy Japonia zaczęła prowadzić politykę bardziej niezależną od USA. Zwłaszcza po kryzysie finansowym 1997 r. stało się jasne, że ten partner ma kluczowe znaczenie w stabilizowaniu rynków finansowych i gospodarek państw regionu. Aspiracje Japonii jako mocarstwa politycznego są powstrzymywane, najchętniej jest ona widziana jedynie jako sojusznik USA i razem z Ameryką stanowi przeciwwagę dla tworzącej się potęgi Chin ${ }^{35}$.

W czasie szczytu manilskiego ASEAN + 3 premier Obuchi zaproponował przyjęcie wspólnego oświadczenia nt. współpracy w Azji Południowo-Wschodniej. Dla Japonii ASEAN jest ważnym partnerem, ponieważ pozytywnie wpływa na bezpieczeństwo w regionie. Podczas konferencji konsultatywnej, która odbyła się w dniach 26-30 marca 2000 r. w Narze (Japonia) strony

${ }^{32}$ China, ASEAN sign MoU on cooperation in security issues, http://www.chinadaily. com.cn/en/doc/2004-01/11content_297791.htm.

${ }^{33}$ Kuik Chen C h w e e, Multilateralizm in China's ASEAN Policy: its Evolution, Characteristics, and Aspiration, „Contemporary Southeast Asia” 2005, Vol. 27, Iss. 1, www.questia.com.

${ }^{34}$ Ibidem.

${ }^{35}$ J. P o t o c k i, op. cit., s. $158-159$. 
wypracowały ramowe kierunki współpracy dwustronnej (z poszczególnymi członkami organizacji) i wielostronnej. Tradycyjnie Japonia koncentruje się na programie ODA (Official Development Assistance), a od niedawna zintensyfikowała swoje inwestycje w nowoprzyjętych państwach ASEAN: Kambodży, Laosie, Myanmarze (Birmie) i Wietnamie. Można uznać, że kolejnym przełomem stała się Deklaracja tokijska (Tokyo Declaration for Dynamic and Enduring ASEAN-Japan Partnership in the New Millenium) z roku 2003, której podstawowym założeniem było wzmocnienie współpracy i utworzenie Wspólnoty Wschodnioazjatyckiej (East Asian Community).

Wydaje się, że wspomniana współpraca ASEAN + 3 (Chiny, Japonia i Republika Korei) przyniosła najbardziej rozbudowane formy w wielu dziedzinach: gospodarczej, społecznej, politycznej i bezpieczeństwa. Rozpoczęła się w grudniu 1997 r., a zinstytucjonalizowaną formę przybrała po szczycie w Manili w roku 1999. Jak było powiedziane, na pierwszym ministerialnym szczycie poświęconym zorganizowanej przestępczości międzynarodowej przyjęto plan działań skierowany przeciw terroryzmowi, piractwu morskiemu, przemytowi, praniu brudnych pieniędzy i handlowi narkotykami. Rośnie współpraca gospodarcza i wymiana handlowa, która w roku 2003 osiagnęła wartość 195,6 mld USD - w porównaniu z 170,8 mld USD rok wcześniej, tj. wzrosła o 14,49\% ${ }^{36}$. Daje to nadzieję na utworzenie $\mathrm{w}$ niedługim czasie strefy wolnego handlu w Azji Wschodniej (EAFTA). Na szczycie w Phnom Penh w 2002 r. przyjęto 17 krótkoterminowych oraz 9 średnio- i długoterminowych przedsięwzięć, które w konsekwencji mają ułatwić powstanie EAFTA. W czasie konferencji ministrów gospodarki w Dżakarcie 14 września 2004 r. postanowiono powołać grupe ekspercką, która będzie zajmować się EAFTA. Ważną inicjatywą ASEAN + 3 jest również utworzenie Azjatyckiego Wspólnego Rynku (ABMI). Postęp we wszystkich wymienionych dziedzinach pozytywnie oceniono w czasie konferencji, która odbyła się 29 listopada 2004 r. w Vientiane ${ }^{37}$. Problemem współpracy ASEAN +3 jest fakt, że Chiny i Japonia - mimo normalizacji stosunków wzajemnych - nadal rywalizują w regionie, mają rozbieżne interesy. W prywatnych rozmowach przedstawiciele Japonii głoszą, że nieprędko $\mathrm{w}$ regionie powstanie strefa wolnego handlu, chociaż podtrzymują ideę ściślejszej współpracy i włączania do niej Chin, aby polepszyć stosunki w Azji Wschodniej ${ }^{38}$.

Perspektywiczną inicjatywą ASEAN +3 było zwołanie szczytu wschodnioazjatyckiego (East Asian Summit - EAS) w Kuala Lupur w grudniu 2005 r. W spotkaniu obok 10 państw-członków ASEAN, uczestniczyły również: Chiny, Japonia, Republika Korei, Australia, Nowa Zelandia, Indie i Rosja jako obser-

\footnotetext{
${ }^{36}$ ASEAN Plus Three Cooperation, http://www.aseansec.org/16580. htm.

${ }^{37}$ Tenth ASEAN Summit, Vientiane 29-30 November 2004, http://www.asensec.org/16474. htm.

${ }^{38}$ D. S i n g h, op. cit., s. 11.
} 
wator. Delegacje przyjęły deklarację, określającą spotkanie jako forum dla dialogu, dotyczącego wszystkich ważnych spraw regionu w imię umacniania pokoju, stabilności i rozwoju gospodarczego w Azji Wschodniej. W deklaracji zaznaczono również, że szczyt może odegrać znaczącą rolę w budowie Wspólnoty Azji Wschodniej. Starzy członkowie ASEAN chca, aby ta organizacja stała się czymś więcej niż stowarzyszeniem, być może nawet silną i niezależną unią wschodnioazjatycką. Kolejny szczyt odbył się na Filipinach, a trzeci był zaplanowany na 21 listopada 2007 r. w Singapurze.

Nie należy zapominać o roli Indii, zwłaszcza w odniesieniu do bezpieczeństwa regionu Azji Południowej i Południowo-Wschodniej, czego wyrazem była wzmożona aktywność dyplomatyczna tego państwa w roku 2000 (wizyty w państwach ASEAN). Indie rozpoczęły współpracę z ASEAN w roku 1992. W marcu następnego roku współpraca została sformalizowana po wymianie listów między sekretarzem generalnym ASEAN, Dato Ajit Singh, a ministrem spraw zagranicznych Indii Shri Dinesh Singh. W grudniu 1995 r., na szczycie w Bangkoku, strony zgodziły się podnieść poziom wzajemnych kontaktów do rangi pełnego partnera dialogu i taką rangę od 1996 r. mają stosunki ASEAN z Indiami. Regularnie odbywają się spotkania w ramach Wspólnego Komitetu Współpracy ASEAN-Indie. Przemawiając na szczycie państw ASEAN w Singapurze 2 czerwca 2000 r. minister spraw zagranicznej w wystapieniu Indie i ASEAN: paradygmat bezpieczeństwa w $2000 \mathrm{r}$. stwierdził, że ARF może odgrywać eksperymentalną rolę $\mathrm{w}$ dziedzinie zapewnienia bezpieczeństwa $\mathrm{w}$ regionie Azji-Pacyfiku w oparciu o pluralizm, współpracę i konsensus w dobie poszukiwania nowego układu międzynarodowego, w okresie odejścia od systemu równowagi sił i wyścigu zbrojeń ${ }^{39}$. Instytucjonalne formy współpracy Indii z ASEAN to m.in.: ARF, PMC, Rada Biznesu ASEAN-Japonia (AJBC), Komitet Współpracy (JCC). Istnieje również projekt włączenia Indii do forum ASEAN + 3 i utworzenia ASEAN + 4, ale sprzeciwia się temu Malezja ze względu na ścisłe powiązania z Pakistanem. W czasie szczytu w Vientiane udało się podpisać Porozumienie o partnerstwie dla pokoju, postępu i dobrobytu oraz szczegółowy plan realizacji współpracy we wszystkich dziedzinach gospodarki, handlu, współpracy politycznej, społecznej, naukowej i w zakresie bezpieczeństwa $^{40}$. Istnieje również program współpracy Mekong-Ganges oraz jest prowadzony dialog $\mathrm{w}$ sprawie utworzenia strefy wolnego handlu. Ważnym celem współpracy jest także walka $\mathrm{z}$ terroryzmem i przestępczością transnarodową. 8 paździenika 2003 r. ASEAN i Indie podpisały na Bali wspólną deklarację o współpracy przy zwalczaniu międzynarodowego terroryzmu. Indie również

${ }^{39}$ India and ASEAN: Security Paradigm AD 2000, http://meadev.nic.in/speeches/asean-june2000.htm.

${ }^{40}$ ASEAN-Indie Partnership for Peace, Progress and Shared Prosperity, Tenth ASEAN Summit, Vientiane 29-30 November 2004. 
w roku 2003 podpisały porozumienie o wszechstronnej współpracy gospodarczej z ASEAN i dwa lata później z Singapurem. Podobne zamiary mają Indie w stosunku do Tajlandii. Utworzono grupy studyjne do podpisania porozumienia o wolnym handlu z Malezją, Indonezją, Japonią i Republiką Korei ${ }^{41}$. W roku 1997 Pakistan rozpoczął również współpracę z ASEAN, ale dotąd nie uzyskał statusu pełnoprawnego partnera dialogu.

Jak już wspominałam, dla bezpieczeństwa regionalnego niezwykle ważny jest rozwój wydarzeń na Półwyspie Koreańskim, stąd od ponad dwudziestu lat ASEAN współpracuje z Republiką Korei. Początek kontaktom dała wymiana listów między szefem Stałego Komitetu ASEAN (ASC) Ali Alatasem i ministrem spraw zagranicznych Korei Choi Ho Joongiem. Pełnoprawnym partnerem dialogu została Korea po szczycie w Kuala Lumpur w roku 1991, a od 2001 r. uczestniczy $\mathrm{w}$ rozwiązywaniu problemów bezpieczeństwa i pokoju $\mathrm{w}$ regionie, $\mathrm{z}$ wykorzystaniem takich instytucji jak: ARF, PMC, ASEAN +1 oraz ASEAN + 3. Korea jest inicjatorem wielu programów, m.in. utworzenia Grupy Studyjnej Azji Wschodniej (East Asia Study Group - EASG), popiera inicjatywe ZOPFAN stworzenia w Azji Południowo-Wschodniej strefy wolnej od broni atomowej, sprzyja wszelkim inicjatywom integracyjnym. Z kolei ASEAN udzielił poparcia „słonecznej” polityce prezydenta Kim Dae Junga i procesowi normalizacji stosunków między dwoma państwami koreańskimi.

Funkcjonuje ponadto Międzyregionalny Dialog Europa-Azja w ramach ASEM (Asia-Europe Meeting). Do tej pory konferencje ASEM odbywały się co dwa lata: inauguracyjna w roku 1996 w Bangkoku, w roku 1998 w Londynie, w roku 2000 w Seulu, w 2002 w Kopenhadze i w 2004 w Hanoi. W czasie konferencji w Seulu wyznaczono kierunki działania dla tego forum w kolejnych latach i oprócz szeregu zagadnień o charakterze współpracy gospodarczej, kulturowej, w dziedzinie ochrony zdrowia i ochrony środowiska strony zdecydowały się podjać współpracę polityczną z poszanowaniem zasad równości, wzajemnego zrozumienia, prawa międzynarodowego, nieingerowania, ani bezpośredniego, ani pośredniego, w sprawy wewnętrzne ${ }^{42}$. Na szczycie w Hanoi (2004 r.), w którym udział wzięły: Japonia, Chiny, Republika Korei, 7 członków ASEAN i 15 członków Unii Europejskiej, dyskusja dotyczyła trzech grup zagadnień: sfery politycznej, ekonomicznej i finansów oraz szeroko pojętych zagadnień cywilizacji, kultury i edukacji. W czasie tego forum przyjęto deklarację w sprawie pokoju na Półwyspie Koreańskim oraz deklarację potępiająca międzynarodowy terroryzm. Kolejny szczyt w ramach ASEM odbył się w 2008 r. w Chinach.

${ }^{41}$ Arabinda Acharya, Indiaand Southeast Asia in the Age of Terror: Building Partnership for Peace, „Contemporary Southeast Asia” 2006, Vol. 28, Iss. 2, www.questia.com.

${ }^{42}$ Asia-Europe Cooperation Framework 2000, http://www.asem3.gokr/english/index01.htm. 


\section{Podsumowanie}

Stowarzyszenie Narodów Azji Południowo-Wschodniej istnieje i doskonali formy swojej działalności mimo istniejących między państwami członkowskimi różnic cywilizacyjnych, gospodarczych, sporów i konfliktów terytorialnych. Zwłaszcza w sferze politycznej, walki o pokój, bezpieczeństwo i stabilizację ASEAN stało się pierwszoplanową organizacją regionalną. Podstawowa doktryna bezpieczeństwa Stowarzyszenia opiera się na obowiązku utrzymywania przez rządy państw członkowskich stałego wzrostu gospodarczego i dobrobytu obywateli, stabilności wewnętrznej i porządku regionalnego. Wzrost gospodarczy ma nie tylko służyć stabilizacji wewnętrznej, lecz także przyczyniać się do eliminowania zagrożeń, konfliktów i rebelii. Wypracowana forma dialogu z mocarstwami globalnymi i regionalnymi pozwala nazwać spory i konflikty, przenosić je z ,pola bitew” do stołu konferencyjnego. Widoczne dzięki stabilizacji politycznej sukcesy gospodarcze sprawiaja, że wola kompromisu i porozumienia jest traktowana przez państwa priorytetowo.

Należy jasno zaznaczyć, że ASEAN nadal nie koordynuje polityki zagranicznej poszczególnych członków. W tym zakresie polityka zagraniczna pozostaje domeną suwerennych państw, niemniej jednak Stowarzyszenie formułuje wspólne cele związane z zapewnieniem bezpieczeństwa i wskazuje na zagrożenia ekonomiczne oraz finansowe w kontekście współdziałania (korelacji) polityki narodowej i regionalnej.

ASEAN cechuje złożona struktura organizacyjna, niejednokrotnie w czasie konferencji państw członkowskich pojawiały się obawy związane z koordynacją prac i sprawnością realizacji powierzonych zadań. Rolę koordynatora różnorodnych inicjatyw powierzono Sekretariatowi ASEAN, a w szczególności sekretarzowi generalnemu, który winien ,inicjować, doradzać, koordynować i czuwać nad realizacją planów".

W podsumowaniu warto zwrócić uwagę na inicjatywę szczytu 16. państw Azji Wschodniej (East Asian Summit), który został zwołany w Kuala Lupur w grudniu 2005 r. Nakreślony strategiczny cel to utworzenie wspólnoty wschodnioazjatyckiej (East Asian Community), stanowiącej 60\% populacji naszego globu, o potencjale gospodarczym większym od potencjału Unii Europejskiej. Wspólnota ta $\mathrm{w}$ dalszej perspektywie może stać się silną i niezależną unią wschodnioazjatycką - równoprawnym graczem na scenie międzynarodowej. 